\title{
EFFECT OF ORGANIC FERTILIZER AND DRY YEAST ON SINAPIS ALBA L. PLANT UNDER SINAI CONDITIONS
}

\author{
Toaima, Wael I.M.
}

Department of Medicinal and Aromatic Plants, Ecology and Dry Lands Agriculture Division, Desert Research Center, 11753 ElMatareya, Cairo, Egypt

E-mail: taema2005@yahoo.com

\begin{abstract}
A
field experiment was conducted during the two successive seasons of 2012/2013 and 2013/2014 in El-Maghara Research Station, Desert Research Center, North Sinai Governorate to study the effect of organic fertilization and foliar spray with active dry yeast on growth, seeds yield and chemical constituents of Sinapis alba L. seeds. The experiment was carried out in split plot design. The main plots were consisted of three application levels of organic fertilization of 3,6 and 9 ton compost per feddan. The sub-plots included foliar spray of active dry yeast at three concentrations $(0,3$ and $6 \mathrm{~g} /$ liter $)$. The interaction effect indicated that the application of the highest compost manure level of 9 ton/fed with foliar spray of the highest yeast concentration of 6 $\mathrm{g} /$ liter led significantly to the highest increments in plant height, dry weight per plant, number of siliquae per plant, seeds yield per plant and per feddan, fixed oil yield per plant and furthermore increased total protein content in the seeds over control treatment. Erucic acid was the main dominant fatty acid in fixed oil composition.
\end{abstract}

Keywords: white mustard, compost, yeast, seeds, fixed oil

White mustard, yellow mustard or Sinapis alba L. (Family Brassicaceae) is an important medicinal and aromatic plant in the world. Its ground seeds are used as a condiment for production of table mustard. Moreover, it is used in folk and modern medicine. The plant is widely native to Mediterranean regions, elsewhere in Eurasia and currently cultivated in many temperate regions of the world (Seidemann, 2005; Elzebroek, 2008; Snyder, 2012 and Nandwani, 2014).

In Egypt, production of medicinal and aromatic plants expanded to the newly reclaimed lands; especially in Sinai Peninsula as a promising land for cultivation and production of medicinal and aromatic plants. Nonetheless, the current problem facing agriculture expansion, there is the lack of information on cultivation processes for many medicinal and 
aromatic plants under Sinai conditions; such as white mustard plants. Thus, the aim of this work was to study the effect of organic fertilization and foliar spray with active dry yeast on growth, seeds yield and seeds chemical constituents of Sinapis alba L. plants under El-Maghara region conditions, North Sinai Governorate.

\section{MATERIALS AND METHODS}

This experiment was conducted during the two successive seasons of 2012/2013 and 2013/2014 in the Agricultural Experimental Station of the Desert Research Center at El-Maghara region $\left(30.71^{\circ} \mathrm{N}\right.$ and $\left.33.33^{\circ} \mathrm{E}\right)$, North Sinai Governorate. The seeds of white mustard plants were sown in the field at $1^{\text {st }}$ of October for both seasons under drip irrigation system at distances of $15 \mathrm{~cm}$ between hills and $60 \mathrm{~cm}$ between rows. After germination, the plants were thinned at two plants per hill (93333 plants/feddan). The soil was carefully prepared and initial soil samples from depth of $0-30 \mathrm{~cm}$ were analyzed and the properties are presented in table (1 and 2). Chemical analysis of water irrigation is shown in table (3).

The experiment was designed in a split plot design with three replications. The main plots were consisted of three application levels of organic fertilization as follows: 3, 6 and 9 ton compost manure per feddan while, the sub-plots included foliar spray of active dry yeast at three concentrations as follows: 0,3 and $6 \mathrm{~g}$ dry yeast/ 1 liter of water. The composition of yeast solution employed in the experiment was described in table (4). Compost manure was added before sowing the date during soil preparation. Half dose of the recommended chemical fertilizers was applied for the experiment according to Migahed et al. (1998). The active dry yeast Saccharomyces cerevisiae (Table 5) was dissolved in water followed by adding sugar at ratio 1:1 and kept overnight for activation and reproduction of yeast (El-Tohamy et al., 2008) and plants were sprayed with yeast culture after 30 and 60 days of sowing date. The plants were harvested on the $13^{\text {th }}$ of March in both seasons L.S.D. test at 0.05 was used to compare the average means of treatments, according to Snedecor and Cochran (1982).

\section{The following data were recorded:}

\section{Growth and Yield Characters}

Plant height $(\mathrm{cm})$, dry weight/plant $(\mathrm{g})$, number of siliquae/plant, number of seeds/siliqua, seeds yield (g/ plant and $\mathrm{kg} / \mathrm{fed}$ ) were recorded.

\section{Seeds Chemical Constituents}

\subsection{Fixed oil percentage}

Soxhlet method was used for estimation of fixed oil in the seeds as stated by the A.O.A.C. (1970).

\subsection{Fixed oil yield per plant}

Fixed oil yield per plant (g) was calculated as follows: Fixed oil

Egyptian J. Desert Res., 66, No. 2, 251-266 (2016) 
percentage $\times$ seeds dry weight per plant $/ 100$

\subsection{Fatty acids}

The methyl esters of fatty acids were done according to Stahl (1967).

The identification of fatty acids was carried out using Gas Liquid

Chromatography apparatus at the Central Laboratory of National Research

Center, Giza, Egypt.

\subsection{Total proteins percentage}

Total proteins percentage (\%) was calculated as follows: $\mathrm{N}(\%)$ x 6.25 .

Table (1). The mechanical analysis of the experimental soil area.

\begin{tabular}{ccccc}
\hline Depth (cm) & Sand (\%) & Silt (\%) & Clay (\%) & Soil texture \\
\hline $0-30$ & 95.00 & 4.00 & 1.00 & Sandy \\
\hline
\end{tabular}

Table (2). The chemical analysis of the experimental soil area.

\begin{tabular}{|c|c|c|c|c|c|c|c|c|c|c|}
\hline \multirow[t]{2}{*}{ pH } & \multirow{2}{*}{$\frac{\text { E.C. }}{(\mathrm{ds} / \mathrm{m})}$} & \multirow{2}{*}{$\begin{array}{c}\text { O.M. } \\
(\%) \\
\end{array}$} & \multicolumn{4}{|c|}{ Soluble anions (meq/l) } & \multicolumn{4}{|c|}{ Soluble cations (meq/l) } \\
\hline & & & $\mathrm{CO}_{3}^{--}$ & $\mathrm{HCO}_{3}$ & $\mathrm{Cl}^{-}$ & $\mathrm{SO}_{4}^{-}$ & $\mathrm{Ca}^{++}$ & $\mathbf{M g}^{++}$ & $\mathrm{Na}^{+}$ & $\mathbf{K}^{+}$ \\
\hline 7.9 & 2.8 & 0.5 & - & 1.0 & 20.0 & 7.0 & 6.0 & 8.0 & 12.6 & 1.4 \\
\hline
\end{tabular}

Table (3). The chemical analysis of irrigation water.

\begin{tabular}{cccccccccc}
\hline pH & E.C. & \multicolumn{4}{c}{ Soluble anions (meq/l) } & \multicolumn{4}{c}{ Soluble cations (meq/l) } \\
\hline & $\mathbf{p p m}$ & $\mathbf{C O}_{3}{ }^{--}$ & $\mathbf{H C O}_{\mathbf{3}}{ }^{-}$ & $\mathbf{C l}^{-}$ & $\mathbf{S O}_{4}{ }^{-}$ & $\mathbf{C a}^{++}$ & $\mathbf{M g}^{++}$ & $\mathbf{N a}^{+}$ & $\mathbf{K}^{+}$ \\
\hline 7.32 & 2547.15 & - & 4.26 & 23.59 & 11.44 & 11.45 & 9.64 & 17.31 & 0.89 \\
\hline
\end{tabular}

Table (4). The chemical analysis of used compost manure.

\begin{tabular}{cccccccccc}
\hline $\begin{array}{c}\text { Bulk Density } \\
\mathbf{k g} / \mathbf{m}^{\mathbf{3}}\end{array}$ & $\begin{array}{c}\text { Moisture } \\
\text { content } \\
(\boldsymbol{\%})\end{array}$ & $\mathbf{p H}$ & $\begin{array}{c}\mathbf{E C} \\
(\mathbf{d s} / \mathbf{m})\end{array}$ & $\begin{array}{c}\mathbf{O} \\
(\boldsymbol{\%})\end{array}$ & $\begin{array}{c}\text { Ash } \\
(\boldsymbol{\%})\end{array}$ & $\begin{array}{c}\mathbf{C} / \mathbf{N} \\
\mathbf{r a t i o} \\
(\boldsymbol{\%})\end{array}$ & $\mathbf{N}(\boldsymbol{\%})$ & $\begin{array}{c}\mathbf{P} \\
(\boldsymbol{\%})\end{array}$ & $\begin{array}{c}\mathbf{K} \\
(\boldsymbol{\%})\end{array}$ \\
\hline 639 & 25 & 7.91 & 5.53 & 25.97 & 74.03 & 10.91 & 1.38 & 0.49 & 0.59 \\
\hline
\end{tabular}


Table (5). The composition of active yeast.

\begin{tabular}{|c|c|c|c|}
\hline Protein & \multicolumn{3}{|c|}{$47 \%$} \\
\hline Carbohydrates & & \multicolumn{2}{|c|}{$33 \%$} \\
\hline Nucleic acids & & \multicolumn{2}{|c|}{$8 \%$} \\
\hline Minerals & & \multicolumn{2}{|c|}{$8 \%$} \\
\hline Lipids & & \multicolumn{2}{|c|}{$4 \%$} \\
\hline \multicolumn{4}{|c|}{ Composition of minerals } \\
\hline $\mathbf{N a}$ & $0.12 \mathrm{mg} / \mathrm{g}$ & $\mathrm{Cu}$ & $8.00 \mu / \mathrm{g}$ \\
\hline $\mathbf{C a}$ & $0.75 \mathrm{mg} / \mathrm{g}$ & $\mathrm{Se}$ & $0.10 \mu / \mathrm{g}$ \\
\hline $\mathbf{F e}$ & $0.02 \mathrm{mg} / \mathrm{g}$ & $\mathrm{Mn}$ & $0.02 \mu / \mathrm{g}$ \\
\hline Mg & $1.65 \mathrm{mg} / \mathrm{g}$ & $\mathrm{Cr}$ & $2.20 \mu / \mathrm{g}$ \\
\hline $\mathbf{K}$ & $21.0 \mathrm{mg} / \mathrm{g}$ & $\mathrm{Ni}$ & $3.00 \mu / \mathrm{g}$ \\
\hline $\mathbf{P}$ & $13.5 \mathrm{mg} / \mathrm{g}$ & $\mathrm{Va}$ & $0.04 \mu / \mathrm{g}$ \\
\hline $\mathbf{S}$ & $13.5 \mathrm{mg} / \mathrm{g}$ & Mo & $0.40 \mu / \mathrm{g}$ \\
\hline $\mathbf{Z n}$ & $0.17 \mathrm{mg} / \mathrm{g}$ & $\mathrm{Sn}$ & $3.00 \mu / \mathrm{g}$ \\
\hline Si & $0.03 \mathrm{mg} / \mathrm{g}$ & $\mathrm{Li}$ & $0.17 \mu / \mathrm{g}$ \\
\hline \multicolumn{4}{|c|}{ Composition of vitamins } \\
\hline Thiamine & & \multicolumn{2}{|c|}{$60-100 \mu / g$} \\
\hline Riboflavin & & \multicolumn{2}{|c|}{$35-50 \mu / \mathrm{g}$} \\
\hline Niacin & & \multicolumn{2}{|c|}{$300-500 \mu / g$} \\
\hline Pyridoxine HCL & & \multicolumn{2}{|c|}{$28 \mu / \mathrm{g}$} \\
\hline Pantorhenate & & \multicolumn{2}{|c|}{$70 \mu / \mathrm{g}$} \\
\hline Biotin & & \multicolumn{2}{|c|}{$1.3 \mu / \mathrm{g}$} \\
\hline Cholin & & \multicolumn{2}{|c|}{$40 \mu / \mathrm{g}$} \\
\hline Folic acid Vit. B 12 & & \multicolumn{2}{|c|}{$5-13 \mu / g$} \\
\hline Vit. B12 & & \multicolumn{2}{|c|}{$0.001 \mu / \mathrm{g}$} \\
\hline
\end{tabular}

\section{RESULTS AND DISCUSSION}

\section{Effect of Organic Fertilization}

\subsection{Growth and yield characters}

The effect of compost treatments on growth and yield characters are presented in Tables (6-11). Results showed that there was a direct and positive relationship between increasing of compost manure application and the increments of both plant height $(\mathrm{cm})$ and plant dry weight $(\mathrm{g} / \mathrm{plant})$. Plant height and plant dry weight reached to their maximum mean values as a result of compost at 9 ton/fed (Tables 6 and 7).

The same trend was observed for yield characters; number of siliquae/plant, number of seeds/siliqua and seed yield as $\mathrm{g} / \mathrm{plant}$ and $\mathrm{kg} / \mathrm{fed}$, which are shown in tables $(8,9,10$ and 11). It can be noticed that, these treatments had a significant effect on yield characters, except number of seeds/siliqua (Table 9).

Egyptian J. Desert Res., 66, No. 2, 251-266 (2016) 


\subsection{Fixed oil percentage and yield}

Data tabulated in tables (12 and 13) clear that, compost treatments had a significant effect on fixed oil percentage and yield (g/plant). Compost at 3 ton/fed resulted in the highest mean values of fixed oil percentage ( 31.78 and $32.33 \%$ ), while compost at 9 ton/fed gave the maximum mean values of fixed oil yield ( 2.73 and $2.70 \mathrm{~g} / \mathrm{plant})$ for the $1^{\text {st }}$ and $2^{\text {nd }}$ seasons, respectively. The increment of fixed oil yield ( $\mathrm{g} / \mathrm{plant}$ ) may be due to the increment of seed yield ( $\mathrm{g} / \mathrm{plant}$ ).

\subsection{Protein content}

Results presented in table (15), revealed that, the highest values of protein percentage $\left(19.54\right.$ and $19.38 \%$ for the $1^{\text {st }}$ and $2^{\text {nd }}$ seasons, respectively) were obtained as a result of compost treatment at 6 ton/fed.

These results are in harmony with those reported by Patel et al. (1996) on Indian mustard (Brassica juncea); Chung and Wang (2000) on Chinese mustard (Brassica chinensis); Zamil et al. (2004) on mustard (Brassica campestris); Hamed (2011) on white mustard (Sinapis alba) and Kansotia et al. (2015) on Indian mustard (Brassica juncea).

\section{Effect of Yeast}

\subsection{Growth and yield characters}

Growth and yield characters were affected by foliar application of yeast, significant differences were detected between yeast treatments, except for number of seeds/siliqua (Table 9). The mean values of plant height were $93.24,101.50$ and $104.94 \mathrm{~cm}$ in the $1^{\text {st }}$ season against $75.80,76.33$ and 76.22 for the $2^{\text {nd }}$ one as a result of 0,3 and $6 \mathrm{~g} / \mathrm{L}$, respectively. So, the maximum mean value of plant height was produced from plants treated with $6 \mathrm{~g} / \mathrm{L}$. Also, the results showed that plant dry weight recorded 25.81, 31.27 and $41.16 \mathrm{~g} /$ plant for the $1^{\text {st }}$ season as well as $25.61,32.84$ and $40.66 \mathrm{~g} / \mathrm{plant}$ for the $2^{\text {nd }}$ one as a result of foliar application of yeast at 0,3 and $6 \mathrm{~g} / \mathrm{L}$, respectively.

The same trend was observed with number of silquae/plant, number of seeds/siliqua as well as seed yield ( $\mathrm{g} / \mathrm{plant}$ and $\mathrm{kg} / \mathrm{fed}$ ) as shown in tables $(8,9,10$ and 11). So, the maximum mean values of yield characters were obtained as a result of yeast at $6 \mathrm{~g} / \mathrm{L}$.

\subsection{Fixed oil percentage and yield}

Data illustrated in tables (12 and 13) indicated that foliar application of yeast had a significant effect in fixed oil percentage and yield (g/plant).

The maximum mean values of fixed oil percentage and yield (g/plant) were obtained as a result of untreated plants and yeast at $6 \mathrm{~g} / \mathrm{L}$, respectively during both seasons. The increment of fixed oil yield may be due to the increment of seed yield ( $\mathrm{g} / \mathrm{plant})$.

\subsection{Protein content}

Yeast foliar application had no a pronounced effect on protein percentage (\%) during both seasons (Table 15). It can be noticed that yeast 
foliar application at $3 \mathrm{~g} / \mathrm{L}$ gave the highest mean values of protein percentage during both seasons.

The obtained results agree with those demonstrated by Ali (2008) on Origanum syriacum and Ezz El-Din and Hendawy (2010) on Borago Officinalis, who proved that using active dry yeast enhanced growth of plants and increased yield characters as well as active constituents.

On the contrary to these results, different yeast concentrations had no significant effect on number of seeds per siliquae. Also, the maximum fixed oil percentage was obtained by the treatment without yeast application.

\section{Effect of the Interaction}

\subsection{Growth and yield characters}

Results presented in tables (6-11), clear that, the combination treatments between compost and yeast foliar application had a significant effect on growth and yield parameters, except number of seeds/siliqua (Table $9)$.

The combination treatment between compost at 9 ton/fed with yeast application at $6 \mathrm{~g} / \mathrm{L}$ gave the maximum mean values of plant height $(113.00$ and $84.00 \mathrm{~cm})$, plant dry weight $(57.11$ and $55.62 \mathrm{~g} / \mathrm{plant})$, number of siliquae/plant (84.33 and 85.00) for the $1^{\text {st }}$ and $2^{\text {nd }}$ seasons, respectively. On the other hand, number of seeds/siliqua reached to its maximum values as a result of the combination treatment between compost at 3 ton/fed without yeast application for the $1^{\text {st }}$ season and the combination between compost at 9 ton/fed with yeast at $6 \mathrm{~g} / \mathrm{L}$ in the $1^{\text {st }}$ and $2^{\text {nd }}$ seasons.

\subsection{Fixed oil percentage, yield and its constituents}

Concerning the effect of combination treatments on fixed oil percentage, it can be noticed that, the interaction between compost at 9 ton/fed without yeast application gave the highest mean value of fixed oil percentage $(34.81 \%)$ during the $1^{\text {st }}$ season while, the interaction between compost at 3 ton/fed without yeast application gave the highest one (34.71\%) during the $2^{\text {nd }}$ season (Table 13 ).

Data tabulated in the same table clear that, the interaction treatments had a significant effect on fixed oil yield ( $\mathrm{g} / \mathrm{plant}$ ) during both seasons. During the $1^{\text {st }}$ season, the maximum mean value of fixed oil yield (2.89 $\mathrm{g}$ /plant) was obtained as a result of compost fertilizer at 9 ton/fed without yeast foliar application. On the other hand, the interaction treatment between compost at 9 ton/fed with foliar application of yeast at $6 \mathrm{~g} / \mathrm{L}$ gave the maximum mean value of fixed oil yield $(2.89 \mathrm{~g} /$ plant $)$ during the $2^{\text {nd }}$ season.

Concerning the effect of interaction between treatments on chemical constituents of fixed oil (Table 14), seven components were identified by GLC analysis and erucic acid was the main component in the oil (Fig. 1 and 2). The constituents of chosen shambles were as follows:

For the treatment of 3 ton compost/fed without foliar spray of yeast, the fixed oil comprised of saturated fatty acids as palmitic acid $(1.55 \%)$ and Egyptian J. Desert Res., 66, No. 2, 251-266 (2016) 
stearic acid $(1.19 \%)$, while unsaturated fatty acids were oleic acid $(8.95 \%)$, linoleic acid (7.99\%), linolenic acid (5.16\%), omega-3 acid (5.23\%) and erucic acid $(64.83 \%)$. For the treatment of 9 ton compost/fed with foliar spray of yeast at $6 \mathrm{~g} /$ liter, the fixed oil comprised of saturated fatty acids as palmitic acid (1.88\%) and stearic acid $(1.11 \%)$, whereas unsaturated fatty acids were oleic acid (12.07\%), linoleic acid (12.88\%), linolenic acid $(8.54 \%)$, omega-3 acid $(4.83 \%)$ and erucic acid $(54.25 \%)$. The obtained chemical composition of fixed oils were coincided by those obtained by Khalid (2004), Hamed (2011) and Abd El-Wahab (2013).

From the previous oil analyses, it is obvious that applied fertilizers increased contents of palmitic, oleic, linoleic, linolenic acids, while decreased erucic acid content over control treatment. Although, because of high erucic content, the produced mustard fixed oil is not suitable for human consumption as mentioned by Food Standards Australia New Zealand (2003).

\subsection{Protein content}

Results involved in table (15) illustrate that the combination treatment had a pronounced effect on protein content (\%). Plants treated with compost at 6 ton/fed with yeast application at $3 \mathrm{~g} / \mathrm{L}$ gave the highest mean values of protein percentage, which recorded 22.25 and $22.03 \%$ for the $1^{\text {st }}$ and $2^{\text {nd }}$ seasons, respectively.

These findings may be attributed to the role of compost manure, which is required to improve the quality of soil organic matter (Rivero et al., 2004) by various ways. When composts are applied to soil, not only degradable substrates and nutrients are supplied, but also a wide range of microorganisms (Ryckeboer et al., 2003), including harmless heterotrophy, but potentially also plant and human pathogens. Compost as an organic material influences agricultural sustainability by improving chemical, physical, biological properties of soils, the fertility and structure of the soil and the moisture holding capacity (Saha et al., 2008). Moreover, active dry yeast is a natural safety biofertilizer causes various promotive effects on plants. It is considered as a natural source of cytokinins, which simulates cell division and enlargement as well as the synthesis of protein, nucleic acid and B-vitamin. It also releases $\mathrm{CO}_{2}$, which reflected in improving net photosynthesis (Amer, 2004 and Kurtzman and Fell, 2005). 
Table (6). Effect of organic fertilization rates, foliar spray of yeast concentrations and their interaction on plant height $(\mathrm{cm})$ of Sinapis alba L. during the two successive seasons of 2012/2013 and 2013/2014.

\begin{tabular}{|c|c|c|c|c|c|c|c|c|}
\hline \multirow{2}{*}{$\mathrm{N}_{\begin{array}{l}\text { Organic } \\
\text { fertilization }\end{array}}^{\text {Yeast }}$} & \multicolumn{4}{|c|}{ First season } & \multicolumn{4}{|c|}{ Second season } \\
\hline & Without & $\begin{array}{l}\text { Yeast at } \\
3 \text { g/liter }\end{array}$ & $\begin{array}{l}\text { Yeast at } \\
6 \mathrm{~g} / \text { liter }\end{array}$ & Mean & Without & $\begin{array}{l}\text { Yeast at } \\
3 \text { g/liter }\end{array}$ & $\begin{array}{l}\text { Yeast at } \\
6 \mathrm{~g} / \text { liter }\end{array}$ & Mean \\
\hline Compost at 3 ton/fed & 84.17 & 98.00 & 99.00 & 93.72 & 71.67 & 72.04 & 72.55 & 72.09 \\
\hline Compost at 6 ton/fed & 100.67 & 100.00 & 102.83 & 101.17 & 72.67 & 73.33 & 72.11 & 72.70 \\
\hline Compost at 9 ton/fed & 94.89 & 106.50 & 113.00 & 104.80 & 83.05 & 83.62 & 84.00 & 83.56 \\
\hline Mean & 4 & 101.50 & 104.94 & & 75.80 & 76.33 & 76.22 & \\
\hline \multicolumn{9}{|l|}{ LSD 0.05} \\
\hline Organic fertilization & \multicolumn{4}{|c|}{3.97} & \multicolumn{4}{|c|}{6.15} \\
\hline Yeast & \multicolumn{4}{|c|}{5.58} & \multicolumn{4}{|c|}{ NS } \\
\hline Organic fertilization $x$ Yeast & \multicolumn{4}{|c|}{9.66} & \multicolumn{4}{|c|}{3.45} \\
\hline
\end{tabular}

Table (7). Effect of organic fertilization rates, foliar spray of yeast concentrations and their interaction on dry weight/plant $(\mathrm{g})$ of Sinapis alba L. during the two successive seasons of 2012/2013 and 2013/2014.

\begin{tabular}{|c|c|c|c|c|c|c|c|c|}
\hline \multirow{2}{*}{ Organic } & \multicolumn{4}{|c|}{ First season } & \multicolumn{4}{|c|}{ Second season } \\
\hline & Without & $\begin{array}{l}\text { Yeast at } \\
3 \text { g/liter }\end{array}$ & $\begin{array}{l}\text { Yeast at } \\
6 \text { g/liter }\end{array}$ & Mean & Without & $\begin{array}{l}\text { Yeast at } \\
3 \text { g/liter }\end{array}$ & $\begin{array}{l}\text { Yeast at } \\
6 \mathrm{~g} / \text { liter }\end{array}$ & Mean \\
\hline Compost at 3 ton/fed & 17.46 & 21.01 & 33.05 & 23.84 & 19.50 & 22.30 & 31.62 & 24.47 \\
\hline Compost at 6 ton/fed & 24.35 & 27.77 & 33.32 & 28.48 & 23.85 & 27.93 & 34.75 & 28.84 \\
\hline Compost at 9 ton/fed & 35.62 & 45.03 & 57.11 & 45.92 & 33.49 & 48.28 & 55.62 & 45.80 \\
\hline Mean & 25.81 & 31.27 & 41.16 & & 25.61 & 32.84 & 40.66 & \\
\hline \multicolumn{9}{|l|}{ LSD 0.05} \\
\hline Organic fertilization & \multicolumn{4}{|c|}{11.90} & \multicolumn{4}{|c|}{4.67} \\
\hline Yeast & \multicolumn{4}{|c|}{5.20} & \multicolumn{4}{|c|}{5.12} \\
\hline Organic fertilization $x$ Yeast & \multicolumn{3}{|c|}{9.00} & & \multicolumn{4}{|c|}{8.87} \\
\hline
\end{tabular}


Table (8). Effect of organic fertilization rates, foliar spray of yeast concentrations and their interaction on number of siliquae/plant of Sinapis alba L. during the two successive seasons of 2012/2013 and 2013/2014.

\begin{tabular}{|c|c|c|c|c|c|c|c|c|}
\hline \multirow{2}{*}{$\mathrm{N}_{\substack{\text { Organic } \\
\text { fertilization }}}^{\text {Yeast }}$} & \multicolumn{4}{|c|}{ First season } & \multicolumn{4}{|c|}{ Second season } \\
\hline & Without & $\begin{array}{l}\text { Yeast at } \\
3 \text { g/liter }\end{array}$ & $\begin{array}{l}\text { Yeast at } \\
6 \text { g/liter }\end{array}$ & Mean & Without & $\begin{array}{l}\text { Yeast at } \\
3 \text { g/liter }\end{array}$ & $\begin{array}{l}\text { Yeast at } \\
6 \text { g/liter }\end{array}$ & Mean \\
\hline Compost at 3 ton/fed & 28.67 & 43.00 & 57.67 & 43.11 & 29.00 & 41.67 & 1.33 & 40.67 \\
\hline Compost at 6 ton/fed & 35.67 & 40.00 & 59.00 & 44.89 & 35.33 & 38.00 & 51.33 & 41.55 \\
\hline Compost at 9 ton/fed & 65.33 & 75.33 & 84.33 & 75.00 & 66.67 & 77.33 & 85.00 & 76.33 \\
\hline Mean & 43.22 & 52.78 & 67.00 & & 43.67 & 52.33 & 62.55 & \\
\hline \multicolumn{9}{|l|}{ LSD 0.05} \\
\hline Organic fertilization & \multicolumn{4}{|c|}{15.12} & \multicolumn{4}{|c|}{9.84} \\
\hline Yeast & \multicolumn{4}{|c|}{7.74} & \multicolumn{4}{|c|}{7.91} \\
\hline Organic fertilization $\mathrm{x}$ Yeast & \multicolumn{4}{|c|}{13.41} & \multicolumn{4}{|c|}{13.69} \\
\hline
\end{tabular}

Table (9). Effect of organic fertilization rates, foliar spray of yeast concentrations and their interaction on number of seeds/siliqua of Sinapis alba L. during the two successive seasons of 2012/2013 and 2013/2014.

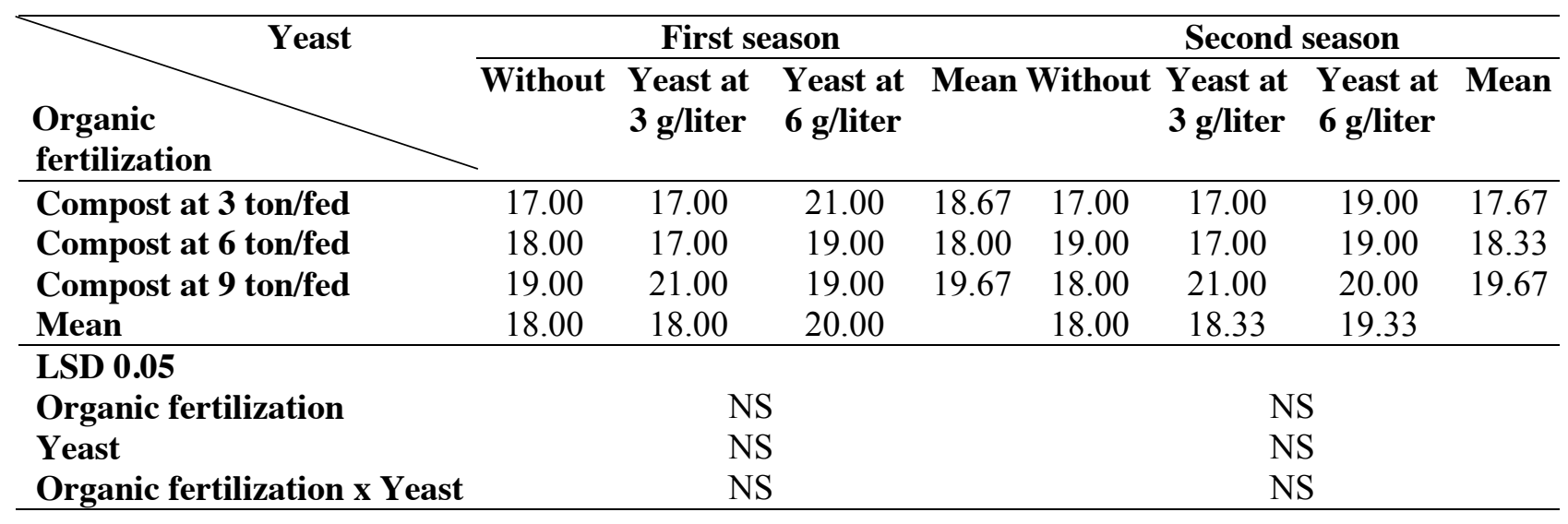


Table (10). Effect of organic fertilization rates, foliar spray of yeast concentrations and their interaction on seeds yield/plant (g) of Sinapis alba L. during the two successive seasons of 2012/2013 and 2013/2014.

\begin{tabular}{|c|c|c|c|c|c|c|c|c|}
\hline \multirow{2}{*}{$\mathrm{P}_{\begin{array}{l}\text { Organic } \\
\text { fertilization }\end{array}}^{\text {Yeast }}$} & \multicolumn{4}{|c|}{ First season } & \multicolumn{4}{|c|}{ Second season } \\
\hline & Without & $\begin{array}{l}\text { Yeast at } \\
3 \text { g/liter }\end{array}$ & $\begin{array}{l}\text { Yeast at } \\
6 \text { g/liter }\end{array}$ & Mean & Without & $\begin{array}{l}\text { Yeast at } \\
3 \text { g/liter }\end{array}$ & $\begin{array}{l}\text { Yeast at } \\
6 \text { g/liter }\end{array}$ & Mean \\
\hline Compost at 3 ton/fed & 2.16 & 4.90 & 6.70 & 4.59 & 3.03 & 5.21 & 6.82 & 5.02 \\
\hline Compost at 6 ton/fed & 4.43 & 5.16 & 7.94 & 5.84 & 4.26 & 4.88 & 7.06 & 5.40 \\
\hline Compost at 9 ton/fed & 8.29 & 9.45 & 12.42 & 10.05 & 7.97 & 9.19 & 12.89 & 10.02 \\
\hline Mean & 4.96 & 6.50 & 9.02 & & 5.09 & 6.43 & 8.92 & \\
\hline \multicolumn{9}{|l|}{ LSD 0.05} \\
\hline Organic fertilization & \multicolumn{4}{|c|}{1.75} & \multicolumn{4}{|c|}{1.02} \\
\hline Yeast & \multicolumn{4}{|c|}{1.06} & \multicolumn{4}{|c|}{1.04} \\
\hline Organic fertilization $\mathrm{x}$ Yeast & \multicolumn{3}{|c|}{1.83} & & \multicolumn{4}{|c|}{1.80} \\
\hline
\end{tabular}

Table (11). Effect of organic fertilization rates, foliar spray of yeast concentrations and their interaction on seeds yield/ fed. $(\mathrm{kg})$ of Sinapis alba L. during the two successive seasons of 2012/2013 and 2013/2014.

\begin{tabular}{|c|c|c|c|c|c|c|c|c|}
\hline \multirow{2}{*}{$\underbrace{\text { Yeast }}_{\begin{array}{l}\text { Organic } \\
\text { fertilization }\end{array}}$} & \multicolumn{4}{|c|}{ First season } & \multicolumn{4}{|c|}{ Second season } \\
\hline & Without & $\begin{array}{l}\text { Yeast at } \\
3 \text { g/liter }\end{array}$ & $\begin{array}{l}\text { Yeast at } \\
6 \text { g/liter }\end{array}$ & Mean & Without & $\begin{array}{l}\text { Yeast at } \\
3 \text { g/liter }\end{array}$ & $\begin{array}{l}\text { Yeast at } \\
6 \text { g/liter }\end{array}$ & Mean \\
\hline Compost at 3 ton/fed & 201.60 & 457.33 & 625.33 & 428.08 & 282.80 & 486.26 & 636.53 & 468.53 \\
\hline Compost at 6 ton/fed & 413.47 & 481.60 & 741.06 & 545.38 & 397.60 & 455.47 & 658.93 & 504.00 \\
\hline Compost at 9 ton/fed & 773.73 & 882.00 & 1159.20 & 938.31 & 743.86 & 857.73 & 1203.06 & 934.88 \\
\hline Mean & 462.93 & 606.98 & 841.86 & & 474.75 & 599.82 & 832.84 & \\
\hline \multicolumn{9}{|l|}{ LSD 0.05} \\
\hline Organic fertilization & \multicolumn{4}{|c|}{162.90} & \multicolumn{4}{|c|}{94.74} \\
\hline Yeast & \multicolumn{4}{|c|}{98.53} & \multicolumn{4}{|c|}{96.93} \\
\hline Organic fertilization $x$ Yeast & \multicolumn{4}{|c|}{170.70} & \multicolumn{4}{|c|}{167.90} \\
\hline
\end{tabular}


Table (12). Effect of organic fertilization rates, foliar spray of yeast concentrations and their interaction on fixed oil percentage in the seeds of Sinapis alba L. during the two successive seasons of 2012/2013 and 2013/2014.

\begin{tabular}{|c|c|c|c|c|c|c|c|c|}
\hline \multirow{2}{*}{$\mathrm{P}_{\begin{array}{l}\text { Organic } \\
\text { fertilization }\end{array}}^{\text {Yeast }}$} & \multicolumn{4}{|c|}{ First season } & \multicolumn{4}{|c|}{ Second season } \\
\hline & Without & $\begin{array}{l}\text { Yeast at } \\
3 \text { g/liter }\end{array}$ & $\begin{array}{l}\text { Yeast at } \\
6 \text { g/liter }\end{array}$ & Mean & Without & $\begin{array}{l}\text { Yeast at } \\
3 \text { g/liter }\end{array}$ & $\begin{array}{l}\text { Yeast at } \\
6 \text { g/liter }\end{array}$ & Mean \\
\hline Compost at 3 ton/fed & 34.13 & 28.84 & 32.37 & 31.78 & 34.71 & 29.01 & 33.26 & 32.33 \\
\hline Compost at 6 ton/fed & 28.98 & 22.72 & 24.68 & 25.46 & 28.97 & 22.72 & 24.50 & 25.40 \\
\hline Compost at 9 ton/fed & 34.81 & 26.42 & 22.62 & 27.95 & 34.70 & 26.58 & 22.13 & 27.80 \\
\hline Mean & 32.64 & 25.99 & 26.56 & & 32.79 & 26.10 & 26.63 & \\
\hline \multicolumn{9}{|l|}{ LSD 0.05} \\
\hline Organic fertilization & \multicolumn{4}{|c|}{1.68} & \multicolumn{4}{|c|}{1.24} \\
\hline Yeast & \multicolumn{4}{|c|}{3.02} & \multicolumn{4}{|c|}{3.41} \\
\hline Organic fertilization $x$ Yeast & \multicolumn{4}{|c|}{5.23} & \multicolumn{4}{|c|}{5.91} \\
\hline
\end{tabular}

Table (13). Effect of organic fertilization, foliar spray of yeast concentrations and their interaction on fixed oil yield per plant (g) of Sinapis alba L. during the two successive seasons of 2012/2013 and 2013/2014.

\begin{tabular}{|c|c|c|c|c|c|c|c|c|}
\hline \multirow{2}{*}{ Organic } & \multicolumn{4}{|c|}{ First season } & \multicolumn{4}{|c|}{ Second season } \\
\hline & Without & $\begin{array}{l}\text { Yeast at } \\
3 \text { g/liter }\end{array}$ & $\begin{array}{l}\text { Yeast at } \\
6 \text { g/liter }\end{array}$ & Mean & Without & $\begin{array}{l}\text { Yeast at } \\
3 \text { g/liter }\end{array}$ & $\begin{array}{l}\text { Yeast at } \\
6 \text { g/liter }\end{array}$ & Mean \\
\hline Compost at 3 ton/fed & 0.74 & 1.41 & 2.16 & 1.44 & 1.05 & 1.51 & 2.26 & 1.61 \\
\hline Compost at 6 ton/fed & 1.28 & 1.17 & 1.95 & 1.47 & 1.23 & 1.11 & 1.73 & 1.36 \\
\hline Compost at 9 ton/fed & 2.89 & 2.49 & 2.81 & 2.73 & 2.77 & 2.45 & 2.89 & 2.70 \\
\hline Mean & 1.64 & 1.69 & 2.31 & & 1.68 & 1.69 & 2.29 & \\
\hline \multicolumn{9}{|l|}{ LSD 0.05 } \\
\hline Organic fertilization & \multicolumn{4}{|c|}{0.39} & \multicolumn{4}{|c|}{0.35} \\
\hline Yeast & \multicolumn{4}{|c|}{0.46} & \multicolumn{4}{|c|}{0.42} \\
\hline Organic fertilization $x$ Yeast & \multicolumn{4}{|c|}{0.79} & \multicolumn{4}{|c|}{0.73} \\
\hline
\end{tabular}


Table (14). Effect of the interaction between treatments on fixed oil chemical constituents (\%) of Sinapis alba L. seeds during the two successive seasons of 2012/2013 and 2013/2014.

\begin{tabular}{|c|c|c|}
\hline Fertilization & $\begin{array}{c}3 \text { ton compost/fed } \\
\text { without foliar spray of yeast } \\
\text { (Control treatment) }\end{array}$ & $\begin{array}{c}9 \text { ton compost/fed } \\
\text { with foliar spray of yeast at } 6 \\
\text { g/liter }\end{array}$ \\
\hline \multicolumn{3}{|l|}{ Fatty acids } \\
\hline Palmitic acid & 1.55 & 1.88 \\
\hline Stearic acid & 1.19 & 1.11 \\
\hline Oleic acid & 8.95 & 12.07 \\
\hline Linoleic acid & 7.99 & 12.88 \\
\hline Linolenic acid & 5.16 & 8.54 \\
\hline $\begin{array}{l}\alpha \text {-linolenic acid (omega-3 } \\
\text { acid) }\end{array}$ & 5.23 & 4.83 \\
\hline Erucic acid & 64.83 & 54.25 \\
\hline Unsaturated Fatty acids & 92.16 & 92.57 \\
\hline Saturated Fatty acids & 2.74 & 2.99 \\
\hline
\end{tabular}

Table (15). Effect of organic fertilization rates, foliar spray of yeast concentrations and their interaction on total protein percentage in the seeds of Sinapis alba L. during the two successive seasons of 2012/2013 and 2013/2014.

\begin{tabular}{|c|c|c|c|c|c|c|c|c|}
\hline \multirow[b]{2}{*}{ fert } & \multicolumn{4}{|c|}{ First season } & \multicolumn{4}{|c|}{ Second season } \\
\hline & Without & $\begin{array}{l}\text { Yeast at } \\
3 \text { g/liter }\end{array}$ & $\begin{array}{l}\text { Yeast at } \\
6 \mathrm{~g} / \text { liter }\end{array}$ & Mean & Without & $\begin{array}{l}\text { Yeast at } \\
3 \text { g/liter }\end{array}$ & $\begin{array}{l}\text { Yeast at } \\
6 \mathrm{~g} / \text { liter }\end{array}$ & Mean \\
\hline Compost at 3 ton/fed & 17.19 & 16.88 & 14.81 & 16.29 & 17.10 & 16.79 & 14.90 & 16.26 \\
\hline Compost at 6 ton/fed & 19.19 & 22.25 & 17.19 & 19.54 & 19.12 & 22.03 & 17.00 & 19.38 \\
\hline Compost at 9 ton/fed & 16.88 & 14.81 & 19.19 & 16.96 & 16.60 & 14.22 & 19.30 & 16.71 \\
\hline Mean & 17.75 & 17.98 & 17.06 & & 17.61 & 17.68 & 17.07 & \\
\hline
\end{tabular}




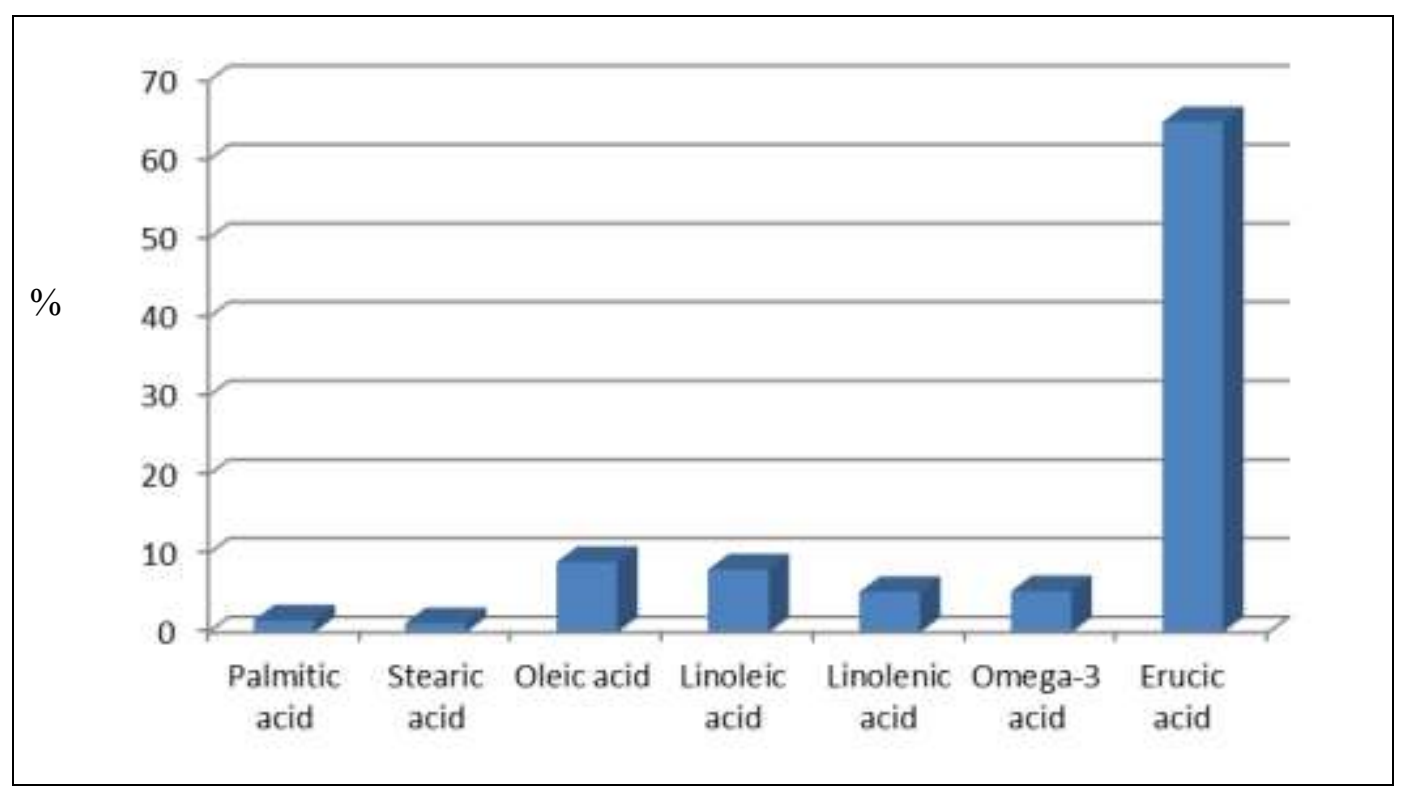

Fig (1). Fixed oil chemical constituents for the treatment of 3 ton compost/fed without foliar spray of yeast.

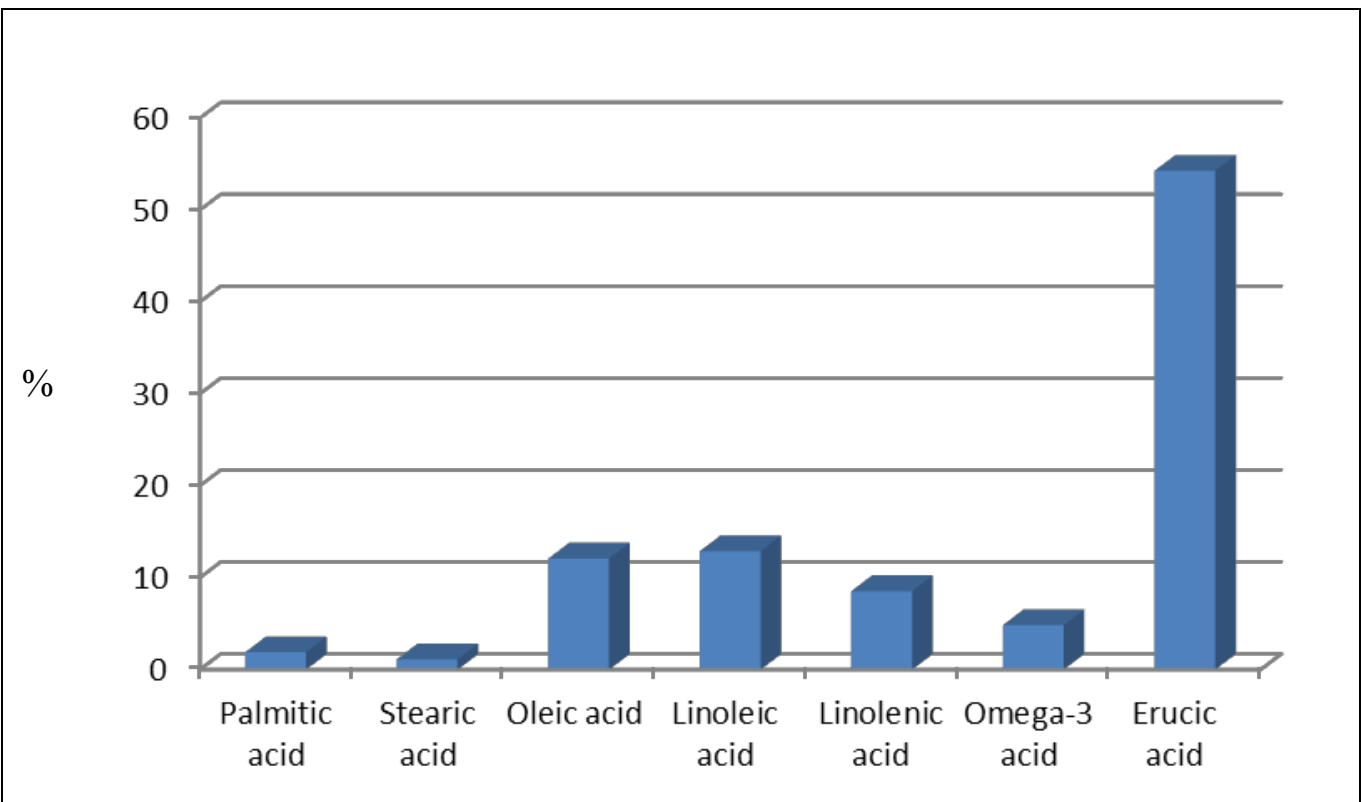

Fig (2). Fixed oil chemical constituents for the treatment of 9 ton compost/fed with foliar spray of yeast at $6 \mathrm{~g} / \mathrm{liter}$.

Egyptian J. Desert Res., 66, No. 2, 251-266 (2016) 


\section{CONCLUSION}

From the foregoing results, it could be concluded that under ElMaghara region conditions, North Sinai Governorate, white mustard plants should be fertilized by compost manure, before sowing throughout soil preparation at the rate of 9 ton/feddan and plants should be foliar sprayed with active dry yeast at the concentration of $6 \mathrm{~g} /$ liter.

\section{REFERENCES}

Abd El-Wahab M. (2013). Decreasing the harmful effect of white mustard irrigation with saline water under North Sinai conditions. Journal of Applied Sciences Research, 9 (6): 3873-3879.

Ali, M.Y.M. (2008). Effect of fertilization, irrigation and planting distances on the growth and production of Origanum syriacum L. plant under Sinai conditions. Ph.D. Thesis, Fac. Agric. Cairo Univ., Egypt.

Amer, S.S.A. (2004). Growth, green pods yield and seeds yield of common bean (Phaseolus vulgaris L.) as affected by active dry yeast, salicylic acid and their interaction. J. Agric Sci. Mansoura Univ., 29 (3): $1407-1422$.

A.O.A.C. (1970). In "Official Methods of Analysis of Association of Official Agriculture Chemists". Washington, D.C., $10^{\text {th }}$ ed.

Chung, R.S. and F.N. Wang (2000). Effect of different composts on growth and nitrogen composition of Chinese mustard in an acid red soil. Communications in Soil Science and Plant Analysis, 31 (9-10): 1209-1224.

El-Tohamy, W.A., H.M. El-Abagy and N.H.M. El-Greadly (2008). Studies on the effect of putrescine, yeast and vitamin $\mathrm{C}$ on growth, yield and Physiological responses of eggplant (Solanum melongena L.) under sandy soil conditions. Australian Journal of Basic and Applied Sciences, 2 (2): 296-300.

Elzebroek, A.T.G. (2008). In "Guide to Cultivated Plants". CABI, 540 pp.

Ezz El-Din, Azza A. and S.F. Hendawy (2010). Effect of dry yeast and compost tea on growth and oil content of Borago Officinalis plant. Research Journal of Agriculture and Biological Sciences, 6 (4): 424430.

Food Standards Australia New Zealand (2003). Erucic Acid in Food: A Toxicological Review and Risk Assessment. Assessment Technical report series No. 21, ISBN 0-642-34526-0, ISSN 1448-3017.

Hamed, E.S. (2011). Study of the effect of fertilization and irrigation levels on growth, production and chemical contents of Brassica alba L. under Sinai conditions. Ph.D. Thesis, Fac. Agric., Kafr El-Sheikh Univ., Egypt.

Egyptian J. Desert Res., 66, No. 2, 251-266 (2016) 
Kansotia, B.C., Y. Sharma and R.S. Meena (2015). Effect of vermicompost and inorganic fertilizers on soil properties and yield of Indian mustard (Brassica juncea L.). Journal of Oilseed Brassica, 6 (1): 198-201.

Khalid, K.A. (2004). Response of white mustard (Sinapis alba L.) plants to calcium superphosphate and phosphorene under calcareous soil conditions. Arab Univ. J. Agric. Sci., Ain Shams Univ., Cairo, 12 (2): 735-747.

Kurtzman, C.P. and J.W. Fell (2005). In "Biodiversity and Ecophysiology of Yeasts". The Yeast Handbook (Gabor P. and C.L. de la Rosa Eds.) Berlin, Springer, p.11-30.

Migahed, H.A., R.N. Kamh and F.A. El-Kased (1998). Effect of N and Zn on the growth, yield, chemical composition and oil production of Brassica alba L. under desert condition. Egypt J. Appl. Sci., 13 (7): 341-349.

Nandwani, D. (2014). In "Sustainable Horticultural Systems". Springer, 395 pp.

Patel, R.H., T.G. Meisheri and J.R. Patel (1996). Analysis of growth and productivity of Indian mustard (Brassica juncea) in relation to FYM , nitrogen and source of fertilizer. J. Agron. Crop Sci., 177 (1): $1-8$.

Rivero, C., T. Chirenje, L.Q. Ma and G. Martinez (2004). Influence of compost on soil organic matter quality under tropical conditions. Geoderma., 123: 355-361.

Ryckeboer, J., J. Mergaert, K. Vaes, S. Klammer, D. De Clercq, J. Coosemans, H. Insam and J. Swings (2003). A survey of bacteria and fungi occurring during composting and self-heating processes. Ann. Microbiol., 53: 349-410.

Saha, S., B.L. Mina, K.L. Gopinath, S. Kundu and H.S. Gupta (2008). Relative changes in phosphatase activities as influenced by source and application rate of organic composts in field crops. Biores. Technol., 99: 1750-1757.

Seidemann, J. (2005). In "World Spice Plants". Springer Science and Business Media, $592 \mathrm{pp}$.

Snedecor, G.W. and Cochran, W.G. (1982). In "Statistical Methods". The Iowa State Univ., Press, Ames, Iowa, U.S.A., 507 pp.

Snyder, C. (2012). In "Herbal Passions". Author House, 536 pp.

Stahl, E.E. (1967). In "Thin Layer Chromatography". A Laboratory Hand Book. Published by Springer Verlag, New York, p. 14-37.

Zamil, S.S., Q.F. Quadir, M.A.H. Chowdhury and A. Al Wahid (2004). Effects of different animal manures on yield, quality and nutrients uptake by mustard cv. Agrani. BRAC Univ. J., 1 (2): 59-66. 


\section{تأثير السماد العضوى والخميرة الجافة على نبات الخردل الأبيض تحت ظروف سيناء}

وائل إسماعيل كحمة طعيمة قسم النباتات الطبية و العطرية ، مركز بحوث الصحر اء ، المطرية، القاهرة ، مصر

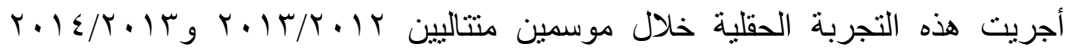

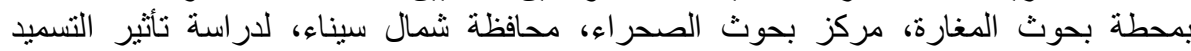

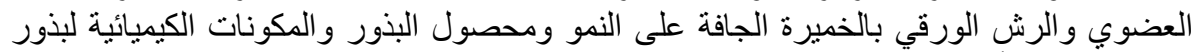

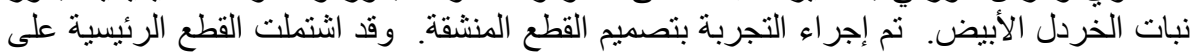

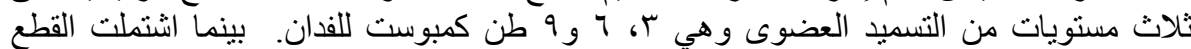

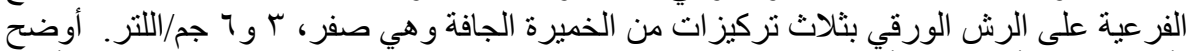

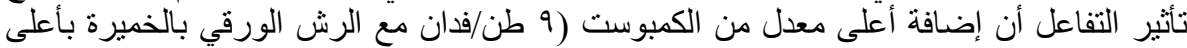

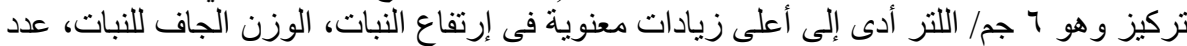

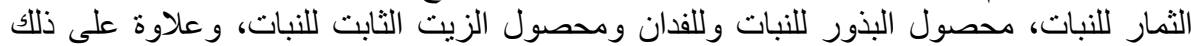

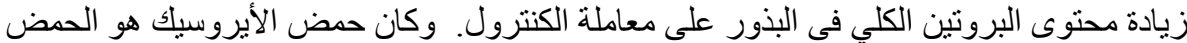
الدهني السائد الرئيسي في تركيب الزيت الثيت الثابت. 